\title{
Assessment of variability in proximate/anti-nutritive composition of cocoyam within Nigeria and Uganda
}

\author{
${ }^{* 1}$ OLATUNDE, KA; ${ }^{2}$ ADEBAYO, K; ${ }^{3}$ MUHUMUZA, J; ${ }^{1}$ BADA, BS
}

${ }^{1}$ Department of Environmental Management and Toxicology, ${ }^{2}$ Department of Agricultural Extension and Rural Development, Federal University of Agriculture Abeokuta, Nigeria *Corresponding author Email: amudatkofoworola@yahoo.com

${ }^{3}$ Mbarara Zonal Agricultural Research and Development Institute, P.O Box 389, Mbarara, Uganda

\begin{abstract}
The availability of cheaper food energy sources which compares favourably with other high priced cereals is of importance and should be encouraged. This study investigated the proximate/anti-nutritive contents of cocoyam collected from Southern Nigeria and Eastern Uganda to investigate if agronomic or climatic factors play a role in its composition. The proximate/mineral composition of cormels (crude protein:0.35 - 6.9\%; carbohydrates: $60.01-83.66 \%$; Fe: $3.65-16.80 \mathrm{mg} / 100 \mathrm{~g}, \mathrm{Zn}: 1.39-2.45 \mathrm{mg} / 100 \mathrm{~g}$ ) show that cocoyam can conveniently replace yams and potatoes in diets due to its similar carbohydrate contents though lower in crude fibre content $(0.99-2.80 \%)$. Cocoyam samples contained high anti-nutrients (Cyanides $0.94-2.16 \%$; Oxalates $8.45-181.4 \mathrm{mg} / \mathrm{Kg}$ ) which may limit its utilization. An analysis of variance indicate cocoyam differ significantly $(\mathrm{p}<0.05)$ in proximate/anti-nutritive contents across the two locations with a higher content of crude fibre, crude protein and carbohydrates observed in samples collected in southern Nigeria.
\end{abstract}

\section{DOI: https://dx.doi.org/10.4314/jasem.v22i5.20}

Copyright: Copyright (C) 2018 Olatunde et al. This is an open access article distributed under the Creative Commons Attribution License (CCL), which permits unrestricted use, distribution, and reproduction in any medium, provided the original work is properly cited.

Dates: Received: 07 April 2018; Revised: 21 April: 2018; Accepted: 24 April 2018

Keywords: Cocoyam, Proximate composition, Nigeria, Uganda

Cocoyam yield cormels in as little as 3 months and can be harvested individually as each matures, or they can be left until all mature and harvested simultaneously (NRC, 2002). They can therefore serve as a cheaper alternative to the expensive tuber such as yam and potatoes, contributing to food security in African countries such as Nigeria and Uganda. They are however generally perceived as a food for the impoverished thereby limiting its research attention which threatens its utilization (Onyeka, 2014). It therefore becomes imperative to assess the nutritional quality of cocoyam cormels in a bid to compare with high priced tubers such as yam and potatoes. Unlike other root and tuber crops, cocoyam contains some anti-nutritive components which have the potential to bind calcium, zinc, iron and other minerals, thereby reducing their availability in the body (Babayemi, 2009). In addition, complex formation of phytic acid with proteins may inhibit the enzymatic digestion of the protein (Adeola and Sands, 2003). The high content of calcium oxalate crystals, about $780 \mathrm{mg}$ per $100 \mathrm{~g}$ in some species of cocoyam, has been implicated in the acridity or irritation caused by cocoyam. Soluble oxalate may combine chemically with calcium to become insoluble oxalate, which is excreted in faeces, reducing absorption of calcium. It may be absorbed into the blood stream where it can combine with serum calcium to form insoluble oxalate crystals (Blaney et al., 1982). This crystal may then precipitate in the kidneys and can cause kidney failure (Lincoln and Black, 1980). Agronomy and climatic has been fingered as a factor influencing the accumulation of anti-nutritive components forage plants (Rahman and Kawamura, 2011). Soil, an essential medium for root/tuber development vary in composition from place to place and may contribute to differences in tubers composition grown in Nigeria and Uganda. Hence, the objective of this study was to assess and compare the proximate composition and anti-nutritive content of cocoyam cormels collected in southern Nigeria and Eastern Uganda.

\section{MATERIALS AND METHODS}

Sample Collection and Preparation: Cocoyam cormels were collected from rural-based cocoyam farmers in southern Nigeria (SN) and Eastern Uganda (EU) using a purposive sampling strategy based on where cocoyam is commonly grown. Samples were transported to the laboratory, peeled and dried in a conventional oven at $105^{\circ} \mathrm{C}$ for 24 hours. The weight loss of fresh cocoyam samples after drying to constant weight will be calculated as moisture content. The 
dried cocoyam samples were milled, labelled and kept in airtight containers in the freezer at $-14^{\circ} \mathrm{C}$ for further analysis.

Laboratory analysis: Proximate Analysis (ash, crude fibre $(\mathrm{F})$, crude protein $(\mathrm{CP})$, crude fat $(\mathrm{CF})$, carbohydrate $(\mathrm{CHO})$ and gross energy $(\mathrm{GE})$ ) were determined using standard analytical procedures (AOAC, 1990). Mineral Analysis (Fe, Mn, Mg, Zn and $\mathrm{Ca}$ ) were determined in cocoyam samples ashed at $550^{\circ} \mathrm{C}$ in a muffle furnace using an atomic absorption spectrophotometer (Perkin Elmer Model 5000). Antinutritive factors were determined using established procedures, oxalate (Chinma, and Igyor 2007), phytates (Okon and Akpanyung 2005), cyanide (Agbaire, 2011), tannins (Makkar, 2003) and saponins (Hiai and Nakajima, 1976).

Data Entry and Analysis: Data obtained from analysis were subjected to descriptive statistics. Separation of means was assessed using the ANOVA tool in the IBM SPSS statistical package 21 .

\section{RESULTS AND DISCUSSION}

The results of the proximate content of cocoyam samples collected in SN and EU are presented in tables 1 and 2. Values are mean \pm SD of 70 samples collected from each sampling locations. Ash content of cocoyam samples were analysed to range between $1.54-3.86 \%$, F: $0.18-1.01 \%$, CF: $0.99-2.80 \%$, CP: $0.35-6.9 \%$, CHO: $60.01-83.66 \%$ and GE: $257.78-$
$367.59 \mathrm{Kcal} / 100 \mathrm{~g}$. An analysis of variance between locations indicates cocoyam samples differ significantly $(\mathrm{p}<0.05)$ in proximate contents across locations with a higher content of $\mathrm{F}, \mathrm{CP}$ and $\mathrm{CHO}$ observed in samples collected in SN. Proximate contents did not differ significantly between the two varieties $(\mathrm{P}>0.05)$. Of utmost importance is its higher protein content which is higher than that found in cassava (2 - 2.7\%) and potatoes (2.5\%) (Apata et al., 1999). Results also show that cocoyam can conveniently replace cassava, yams and potatoes in diets due to its similar CHO contents. It however has a lower F content $(0.99-2.80 \%)$ compared to contemporary root crops and consumption may require amendments with other fibre rich containing foods to avoid diseases such as constipation, pile and appendicitis(Olaleye et al., 2013). Mineral content of cocoyam samples ranged between Fe: 3.65 - 16.80 $\mathrm{mg} / 100 \mathrm{~g}, \mathrm{Mn}: 0.44-2.22 \mathrm{mg} / 100 \mathrm{~g}, \mathrm{Mg}: 22.96-85.75$ $\mathrm{mg} / 100 \mathrm{~g}, \mathrm{Zn}: 1.39-2.45 \mathrm{mg} / 100 \mathrm{~g}$ and $\mathrm{Ca}: 1.61-$ $11.56 \mathrm{mg} / 100 \mathrm{~g}$. Concentrations of $\mathrm{Fe}, \mathrm{Mg}$ and $\mathrm{Zn}$ are consistent with the observations of Mwenye et al (2011). There were significant $(\mathrm{P}<0.05)$ differences in the minerals content of samples across the locations but no significant difference across variety. The differences in the mineral compositions of cocoyam across locations may be associated with differences in the exchangeable mineral contents of soils important for root development (Li et al., 2005).

Table 1: Proximate content of Cocoyam from Nigeria and Uganda

\begin{tabular}{lllllllll}
\hline Location & & $\mathrm{MC} \%$ & $\mathrm{Ash} \%$ & $\mathrm{CF} \%$ & $\mathrm{~F} \%$ & $\mathrm{CP} \%$ & $\mathrm{CHO} \%$ & $\mathrm{GE} \mathrm{Kcal} / 100 \mathrm{~g}$ \\
\hline SN & Total & $19.22 \pm 1.45$ & $2.25 \pm 0.46_{\mathrm{a}}$ & $0.77 \pm 0.15_{\mathrm{a}}$ & $1.54 \pm 0.22_{\mathrm{a}}$ & $5.68 \pm 0.74_{\mathrm{a}}$ & $80.54 \pm 1.74_{\mathrm{a}}$ & $351.86 \pm 5.79_{\mathrm{a}}$ \\
& Tannia & $23.17 \pm 1.45$ & $2.23 \pm 0.45$ & $0.77 \pm 0.16$ & $1.48 \pm 0.21$ & $5.55 \pm 0.79$ & $80.78 \pm 1.79$ & $352.33 \pm 5.83$ \\
& Taro & $25.32 \pm 1.46$ & $2.30 \pm 0.50$ & $0.77 \pm 0.14$ & $1.66 \pm 0.18$ & $5.97 \pm 0.50$ & $79.97 \pm 1.54$ & $350.73 \pm 5.45$ \\
EU & Total & $20.24 \pm 2.36$ & $3.38 \pm 0.50_{\mathrm{b}}$ & $0.45 \pm 0.13_{\mathrm{b}}$ & $2.27 \pm 0.31_{\mathrm{b}}$ & $3.52 \pm 0.74_{\mathrm{b}}$ & $63.12 \pm 2.05_{\mathrm{b}}$ & $270.71 \pm 9.80_{\mathrm{b}}$ \\
& Tannia & $17.30 \pm 1.9$ & $3.53 \pm 0.30$ & $0.47 \pm 0.12$ & $2.36 \pm 0.18$ & 3.420 .71 & $62.91 \pm 1.33$ & $269.59 \pm 6.58$ \\
& Taro & $26.65 \pm 4.50$ & $2.65 \pm 0.65$ & $0.38 \pm 0.14$ & $1.84 \pm 0.44$ & $4.01 \pm 0.69$ & $64.14 \pm 4.11$ & $276.12 \pm 16.84$ \\
& Range & & $1.54-3.86$ & $0.18-0.01$ & $0.99-2.80$ & $0.35-6.9$ & $60.01-83.66$ & $257.78-367.59$ \\
\hline
\end{tabular}

Subscripts $a, b$ indicate comparison along columns

Table 2: Mineral composition of cocoyam

\begin{tabular}{lllllll}
\hline & & $\mathrm{Fe}(\mathrm{mg} / 100 \mathrm{~g})$ & $\mathrm{Mn}(\mathrm{mg} / 100 \mathrm{~g})$ & $\mathrm{Mg}(\mathrm{mg} / 100 \mathrm{~g})$ & $\mathrm{Zn}(\mathrm{mg} / 100 \mathrm{~g})$ & $\mathrm{Ca}(\mathrm{mg} / 100 \mathrm{~g})$ \\
\hline $\mathrm{SN}$ & Total & $13.31 \pm 1.41_{\mathrm{a}}$ & $0.66 \pm 0.17_{\mathrm{a}}$ & $24.68 \pm 1.08_{\mathrm{a}}$ & $1.64 \pm 0.09_{\mathrm{a}}$ & $2.81 \pm 0.76_{\mathrm{a}}$ \\
& Tannia & $13.50 \pm 1.26$ & $0.644 \pm 0.18$ & $24.65 \pm 1.02$ & $1.64 \pm 0.09$ & $2.88 \pm 0.73$ \\
& Taro & $12.85 \pm 1.67$ & $0.71 \pm 0.16$ & $24.76 \pm 1.24$ & $1.65 \pm 0.10$ & $2.65 \pm 0.82$ \\
$\mathrm{EU}$ & Total & $3.97 \pm 0.23_{\mathrm{b}}$ & $1.91 \pm 0.17_{\mathrm{b}}$ & $83.78 \pm 1.21_{\mathrm{b}}$ & $2.05 \pm 0.13_{\mathrm{b}}$ & $10.38 \pm 1.46_{\mathrm{b}}$ \\
& Tannia & $3.96 \pm 0.21$ & $1.91 \pm 0.16$ & $83.79 \pm 1.14$ & $2.06 \pm 1.13$ & $10.62 \pm 0.38$ \\
& Taro & $3.99 \pm 0.32$ & $1.91 \pm 0.21$ & $83.75 \pm 1.54$ & $2.00 \pm 0.12$ & $9.49 \pm 0.26$ \\
& Range & $3.65-16.80$ & $0.44-2.22$ & $22.96-85.75$ & $1.39-2.45$ & $1.61-11.56$ \\
\hline
\end{tabular}

Subscripts $a, b$ indicate comparison along columns

Table 3: Anti-nutrient content of cocoyam

\begin{tabular}{lllllll}
\hline Location & & Tannins mg/kg & Saponins \% & Phytate $\mathrm{mg} / \mathrm{kg}$ & Cyanide $\mathrm{mg} / \mathrm{kg}$ & Oxalate $\mathrm{mg} / \mathrm{kg}$ \\
\hline SN & Total & $1348.24 \pm 567.01_{\mathrm{a}}$ & $0.71 \pm 0.48 \mathrm{a}$ & $14.81 \pm 3.58_{\mathrm{a}}$ & $1.75 \pm 0.49_{\mathrm{a}}$ & $76.58 \pm 42.39_{\mathrm{a}}$ \\
& Tannia & $1413.41 \pm 632.85$ & $0.72 \pm 0.47$ & $14.72 \pm 3.86$ & $1.69 \pm 0.25$ & $84.42 \pm 42.38$ \\
& Taro & $1189.95 \pm 380.55$ & $0.67 \pm 0.51$ & $15.04 \pm 2.89$ & $1.90 \pm 0.11$ & $57.54 \pm 37.23$ \\
EU & Total & $852.16 \pm 131.55 \mathrm{~b}$ & $0.65 \pm 0.35 \mathrm{~b}$ & $13.52 \pm 3.71 \mathrm{~b}$ & $1.45 \pm 0.19 \mathrm{~b}$ & $50.72 \pm 3.45 \mathrm{~b}$ \\
& Tannia & $842.83 \pm 110.30$ & $0.62 \pm 0.21$ & $13.58 \pm 3.90$ & $1.59 \pm 0.41$ & $50.64 \pm 3.14$ \\
& Taro & $888.15 \pm 201.39$ & $0.71 \pm 0.40$ & $13.31 \pm 3.11$ & $1.32 \pm 0.16$ & $51.02 \pm 4.77$ \\
& Range & $221.45-2804.21$ & $0.49-1.04$ & $7.46-29.00$ & $0.94-2.16$ & $8.45-181.4$ \\
\hline \multicolumn{7}{c}{ Subscripts $a, b$ indicate comparison along columns }
\end{tabular}


Cocoyam samples contained anti-nutrients within the range: Tannins 221.45 - $2804.21 \mathrm{mg} / \mathrm{Kg}$, Saponins 0.49 - $1.04 \%$, Phytates: 7.46 - $29.00 \mathrm{mg} / \mathrm{Kg}$, Cyanides $0.94-2.16 \%$ and Oxalates 8.45 - 181.4 $\mathrm{mg} / \mathrm{Kg}$ (Table 3). High anti-nutrient contents in roots and tuber crops are known bind with essential ions such as Iron, calcium and magnesium in the body thereby reducing their bioavailability. This result in diseases associated with mineral deficiencies. Tanin, Phytate and oxalic acids in cocoyam collected in EU were observed to be significantly $(\mathrm{P}<0.05)$ different from those collected in SN.

Conclusion: This study shows that cocoyam can compare favourably well with other contemporary root crops like cassava and potatoes with respect to its proximate and mineral contents. It also contains high contents of anti-nutrients compared with other root and tuber crops. A comparison of samples collected shows significant differences in contents collected from SN and EU but no significant difference across variety. This may be associated with differences in the quality and composition of soils in the two regions.

Acknowledgements: The author(s) wish to acknowledge the kind support of the International Foundation for Science (IFS) through a Grant with No $\mathrm{J} / 5530-1$.

\section{REFERENCES}

Adeola O; Sands, JS (2003). Does supplemental dietary microbial phytase improve amino acid utilization? A perspective that it does not. J. Animal Sci. 81 (14): 7885

AOAC (1990). Official methods of analysis of the association of official analytical chemists. 15 th edition. Washington D.C

Agbaire, PO (2011). Nutritional and anti-nutritional levels of some local vegetables (Vernomia anydalira, Manihot esculenta, Teiferia occidentalis, Talinum triangulare, Amaranthus spinosus) from Delta State, Nigeria. J. Appl. Sci. Environ. 15 (4):625 - 628

Apata, DF; Babalola, TO (1999). The use of cassava, sweet potato and cocoyam, and their by-products by non ruminants. Int. J. of Food Sci. Nutri. Eng. 2(4): 54-62

Babayemi OJ (2009). Nutrient value and in vitro gas production of african wild cocoyam (Colocasia esculentum). Afri. J. of Food Agric. Nutri. Dev. 9 (1):593-607
Blaney, B J; Gartner, RJ; Head, TA (1982). The effects of oxalate in tropical grasses on calcium, phosphorus and magnesium availability to cattle. J. Agric. Sci. 99: 533539.

Chinma, CE; Igyor, MA (2007). Micronutrients and antinutritional contents of selected tropical vegetables grown in Southeast, Nigeria. Nig. Food J. 25(1): 111116

Hiai, S; Nakajima, T (1976). Color reaction of some sapogenins and saponins with vanillin and sulfuric acid. Planta Med. 29:116-122.

Olaleye MT; Komolafe K; Akindahunsi AA (2013). Effect of methanolic leaf extract of Parkia biglobosa on some biochemical indices and hemodynamic parameters in rats. J. Chem. Pharm. Res. 5:213-220.

Onyeka, J (2014). Status of Cocoyam (Colocasia esculenta and Xanthosoma spp) in West and Central Africa: production, household importance and the threat from leaf blight. Lima (Peru). CGIAR Research Program on Roots, Tubers and Bananas (RTB). Available online at: www.rtb.cgiar.org

Li, B; Pattenden, SG; Lee, D; Gutierrez, J; Chen, J; Seidel, C; Gerton, J; Workman, JL (2005). Preferential occupancy of histone variant $\mathrm{H} 2 \mathrm{AZ}$ at inactive promoters influences local histone modifications and chromatin remodeling. Proc. Natl. Acad. Sci. USA (102) 18385-18390

Lincoln, SD; Black, B (1980). Halogeton poisoning in range cattle. J. Am. Vet. Med. Assoc. 176:717-718.

Makkar, HP (2003). Quantification of tannins in tree and shrub foliage: a laboratory manual. Kluwer Academic Publishers, Dordrecht, The Netherlands.

Mwenye, OJ; Demo, P; Pamkomela, P; Chiipanthenga, M; Chipungu, F; Benesi, I; Chimwala. L (2011). A proposal for the release of promising solanum potato varieties and clones in Malawi. Department of Agricultural Research Services, (Unpublished), 1: 516.

National Reasearch Council. (2002). Underexploited Tropical Plants with Promising Economic Value. The Minerva Group, Inc.,

Okon, EU; Akpanyung, EO (2005). Nutrients and antinutrients in selected brands of malt drinks produced in Nigeria. Pakistan Journal of Nutrition 4 (5):352-355.

Rahman, MM; Kawamura, O (2011). Oxalate accumulation in forage plants: some agronomic, climatic and genetic aspects. Asian-Aust. J. Anim. Sci. 24(3): 439 - 448 